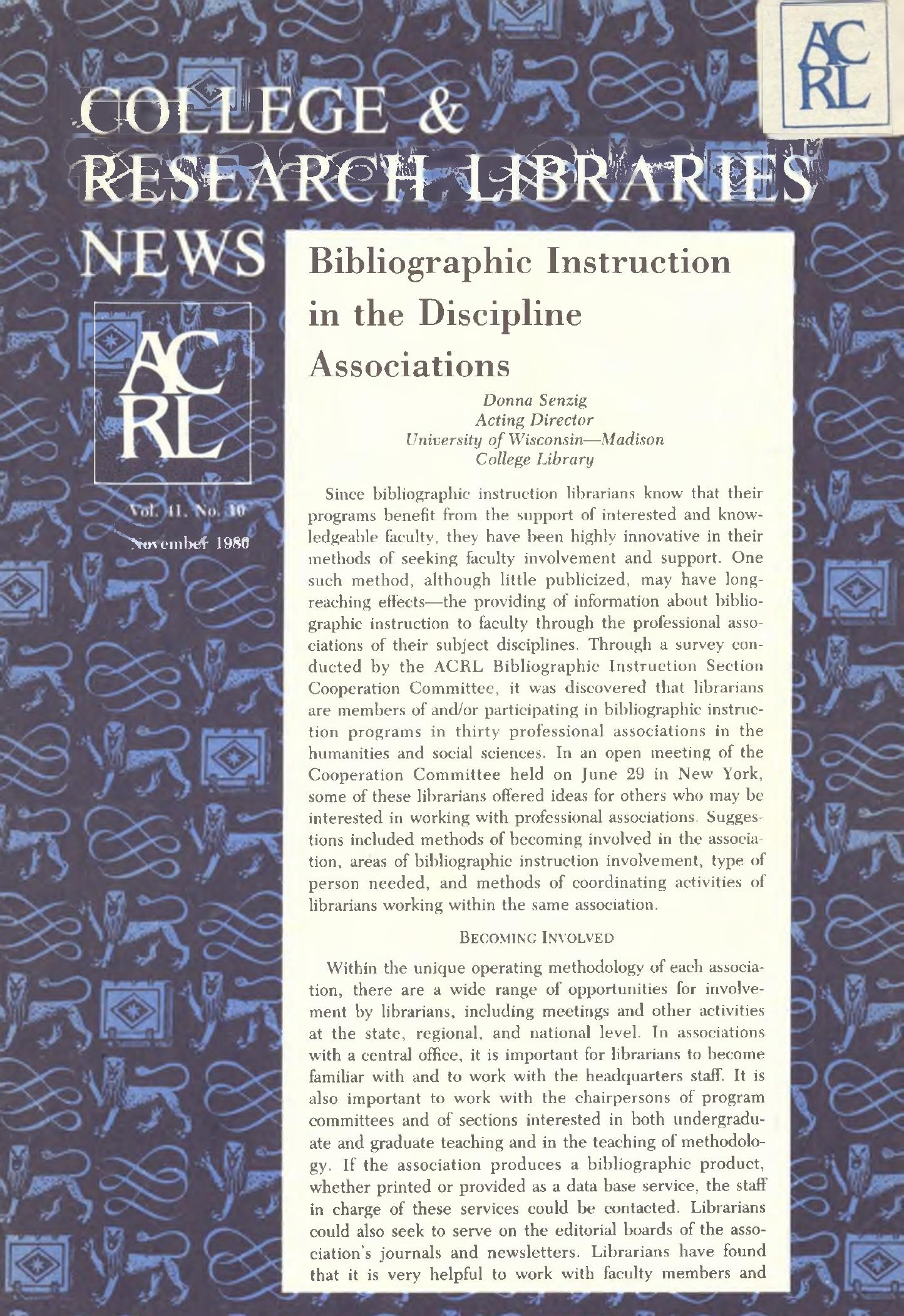


In this issue:

\section{Bibliographic Instruction in the Discipline}

Associations

ACRL Seeks Volunteers

Community Colleges and Networking in New Jersey...305

\section{Continuing Education: Continuing Education at Harvard}

News from the Field 308

People 314

Publications

Calendar

Classified Advertising 324
College \& Research Libraries News is published by the Association of College and Research Libraries, a division of the American Library Association, as 11 monthly (combining JulyAugust) issues, at $50 \mathrm{E}$. Huron St. Chicago, IL 60611. Annua cluded in dues. Single copies and back issues, \$2 each Second-class postage applied for at Chicago, Illinois, and at additional mailing offices (ISSN 0099-0086)

Editor: George M. Eberhart, ACRL/ALA, $50 \mathrm{E}$. Huron St. Chicago, IL 60611: (312) 944-6780, Ext. 288. President ACRL: Millicent D. Abell. Executive Secretary, ACRL; Julie Car roll Virgo.

Production and circulation office: 50 E. Huron St., Chicago, IL 60611 . Display advertising should be sent to Leona Swiech. Advertising Traffic Coordinator. ALA, at above address. Send classified ads to ACRL Change of address and subscription orders should be addressed to College \& Research Libraries News, for receipt at the above address at least two months before the publication date of the effective issue.

nclusion of an article or advertisement in C\&RL News does not constitute official endorsement by ACRL or ALA.

A partial list of the services indexing or abstracting the contents of C\&RL News includes: Current Contents: Social \& Be havior Sciences; Current Index to Journals in Education; In formation Science Abstracts; Library \& Information Science Abstracts; Library Literature; and Social Sciences Citation Index.

(c) American Library Association 1980. All material in this journal subject to copyright by the American Library Association may be photocopied for the noncommercial purpose of scientific or educational advancernent. others who have a $\mathrm{Ph} . \mathrm{D}$. in the field in order to develop a faculty/librarian team approach in the presentation of programs and papers on bibliographic instruction.

\section{AREAS OF INVOLVEMENT}

Librarians, either singly or as a faculty/librarian team, have presented papers and programs on bibliographic instruction and how bibliographic instruction can make teaching more effective. Articles and book reviews on bibliographic instruction can be provided for the journals and newsletters of the association. Bibliographic teaching aids for the field can be prepared by librarians for marketing by the association as well as teaching guides to the bibliography published by the association. Other areas of involvement related to bibliographic instruction might include participating in the design of the association's data base from the user perspective; providing training institutes to teach the use of the data base; formulating library accreditation standards for the field; serving as an editor of the association's publications; and preparing bibliographies and research tools for the field

\section{Personal Characteristics}

Any librarian interested in working with a discipline association should be an active member of the association and be highly motivated to do the groundwork necessary to establish contacts and to promote the visibility and credibility of bibliographic instruction. It is useful but not always necessary to have a $\mathrm{Ph} . \mathrm{D}$. in the field. Writing and speaking skills are important, but in addition the librarian should be familiar with other bibliographic instruction librarians who can be called upon to give high quality papers and programs and to prepare articles or other informative materials that will meet the given need of the association.

\section{Coondination of Activities}

Librarians participating in bibliographic instruction activities within discipline associations have often felt handicapped by the difficulty of identifying other librarians within the same association and by the lack of communication between librarians in different associations. The Cooperation Committee is interested in compiling a directory of librarians who have experience in giving a program in bibliographic instruction to a discipline association and of librarians who are members of a discipline association and would be interested in promoting bibliographic instruction activities. Interested persons who are not now on the mailing list of the Cooperation Committee may contact Donna Senzig, University of Wisconsin College Library, 600 North Park Street, Madison, WI 53706. 